\title{
Investigation on the effect of aqueous Leaf extract of Acanthus montanus on spermatogenesis in Swiss mice
}

\author{
Eme Efioanwan Orlu ${ }^{1}$ and Adetutu Obulor ${ }^{1}$ \\ Department of Applied and Environmental Biology \\ Rivers State University of Science \&Technology Nkpolu, Port Harcourt Rivers State, Nigeria
}

\begin{abstract}
Acanthus montanus T. Anderson (Acanthaceae) possesses several medicinal properties; it is used in Cameroon as a folk medicine to treat pain, inflammation and threatened abortion. The aim of this study was to determine the effect of A. montanus aqueous extract on spermatogenesis in Swiss male albino mice and its mechanism of action.The extract, irrespective of dose, reversibly improved spermatogenic activity with $500 \mathrm{mg} / \mathrm{kg}-1 \mathrm{~b}$.wt giving the most promising result. No significant reduction in body weight and weight of reproductive organs was observed and the gonadosomatic index remained stable irrespective of the increase in concentration of extract of A.momtanus. Increase in the spermatogenic indexes and total spermatogenic yield points to the potential of Acanthus montanus as a herbal-based remedy for spermatogenic dysfunction.
\end{abstract}

\section{Introduction}

Acanthus montanus (T.Anderson) an Acanthace commonly known as Bear's Breeches is a plant with several medicinal uses. Fresh leaves extract has been reported in folk medicine to relieve aches, pains, cough, epilepsy [1] inflammation, false labour and threatened abortion.[1; 2].The use of the root extract in the treatment of urinogenital infections, urethral pains, endometriosis, cyctitis have also been documented [3]. Pharmacological studies showed that the plant has spasmolytic and analgesic effect [4;3], anti inflammatory and antipyretic [5] activities hence this investigation was carried out to determine the effect of the plant leaves extract on some vital organs in mice. Appreciable preimplantation losses while none of the doses caused postimplantation losses [6]. The extract also caused delayed fetal growth.[5].Antifertility and foetotoxic effect has been reported in Wistar rats at $1000 \mathrm{mg} / \mathrm{kg}$ bw .This plant is devoid of toxic effect in rat at the doses often used by the population to treat inflammatory and analgesic ailment [7].Phytochemical screening of Acanthus montanus extract revealed the presence of alkaloids, tannins, glycosides, carbohydrates and steroids [3]. The present study was undertaken to evaluate the effect of A.montanus leaf extract on spermatogenesis on Swiss male albino mice due to the paucity of information of this plant extract on male reproductive health.

\section{Experimental Location}

\section{Materials And Methods}

This investigation was carried in the Department of Applied and Environmental Biology, Rivers State University of Science \&Technology, Port Harcourt [Coordinates 448'14" N 6 59'12”E]. The experiment was conducted between September to December 2013.

\subsection{Preparation of plant extract}

Fresh leaves of Acanthus montanus were collected from RSUST staff quarters. The leaves were cleaned, shredded and kept at $4{ }^{\circ} \mathrm{C}$ prior to use. $20 \mathrm{~g}$ of the leaves were blended and dissolved in $1000 \mathrm{ml}$ of distilled water which forms $100 \%$ concentration of the solution. Serial dilution was made to produce a $50 \%$ concentration of the stock.

\subsection{Experimental Procedure and Animal Manage ment}

Mature Swiss male albino mice were purchased from Sulex Farms for Laboratory Animals, Lagos, and kept in cages for at least 14 days to acclimate them to laboratory conditions and allowed free access to pellet and water. Mice were divided into three groups containing ten male mice each. Concentrations of $1000 \mathrm{mg} / \mathrm{kg}$ /bodyweight and $500 \mathrm{mg} / \mathrm{kg} /$ body weight were administered orally to the test animals while the control group received distilled water for 21 days.

Twenty four hours to the end of the investigation, feed was withheld and all mice were euthanized by the use of Ethyl Ether, dissected and the reproductive organ removed intact. The testes and liver were freed of all adhering tissues and weighed [8]. Known weight of testis of each mouse was immediately fixed in $10 \%$ formalin for $24 \mathrm{hrs}$ for histological assessment. 


\subsection{Testicular Histology and Histometry}

Following fixation, samples were dehydrated in a series of ethyl alcohol, cleared in chloroform and embedded in paraffin. Histological sections $5 \mu \mathrm{m}$ thick were stained with Hematoxylin and eosin [9].

Testicular cross sections of experimental mice were observed at low power(X10) objective and the seminferous epithelium evaluated in detail at X100 immersion oil lens using a digital Microscope Model DB1-180M.The photomicrographs of the epithelium captured with CCD Camera were processed with a DN-2 Microscopy Image Processing Software [10]

\subsection{Seminiferous tubule cell Populations}

The volume percent of round spermatids and other spermatogenic elements was determined following corrections made for retraction of the testicular parenchyma during histological processing [8]. The number of germ cells and Sertoli cells in tubular cross sections were determined in a total of 100 cross sections of the seminiferous tubule. The raw counts were transformed to nuclear true counts [11;12]. The germ cell volumetric proportion was estimated by counting each cell nucleus within the cross sectioned tubule, including Sertoli cells . The following cell-types were quantified : type-A spermatogonia (SpgA), primary spermatocytes at preleptotene/leptotene ( $\left.1^{\circ} \mathrm{spcP} / \mathrm{L}\right)$, pachytene ( $\left.\mathrm{P}\right)$, round spermatids (Rtds) and Sertoli cells (S)

\subsection{Statistical analysis}

The mean and standard deviation were calculated and the differences in means calculated using the Student's ttest.

\section{Results}

The data on body weight and testicular weights are shown in Table 1.There was no significant difference in the body weight, gross Testes weight (TW) and testicular parenchyma weight (TPW) of mice treated with aqueous leaves extract of Acanthus montanus and the control animals.Body weight increase of $5.30 \%, 7.80 \%$ and $6.84 \%$ was recorded in control,500mg/kg and $1000 \mathrm{mg} / \mathrm{kg}$ groups respectively.There was no significant difference in the gonadosomatic indexes (GSI) between the control and the treated animals

Table 1. Effect of aqueous extract of Acanthus montanus leaves on body weights and Gonadosomatic index of the Swiss mice

\begin{tabular}{|llllccc|}
\hline $\begin{array}{l}\text { Treatment } \\
\text { A.montanus } \\
(\mathbf{m g} / \mathbf{k g ~ b w}\end{array}$ & $\begin{array}{l}\text { Initial weight } \\
(\mathbf{g})\end{array}$ & $\begin{array}{l}\text { Final weight } \\
(\mathbf{g})\end{array}$ & $\begin{array}{l}\text { Weight gain } \\
(\mathbf{g})\end{array}$ & $\begin{array}{l}\text { Increase in } \\
\text { Body weight } \\
(\boldsymbol{\%})\end{array}$ & $\begin{array}{l}\text { Paired Testes } \\
\text { Weight }(\mathbf{g})\end{array}$ & $\begin{array}{l}\text { Gonadosomatic } \\
\text { Index }(\%)\end{array}$ \\
\hline Control & $44.62 \pm 1.27$ & $47.11 \pm 2.54$ & $2.49 \pm 1.45$ & 5.30 & $0.25 \pm 0.02$ & 0.53 \\
\hline $\mathbf{5 0 0}$ & $43.93 \pm 1.43$ & $47.65 \pm 2.64$ & $3.72 \pm 1.38$ & 7.80 & $0.36 \pm 0.07$ & 0.76 \\
\hline \hline $\mathbf{1 0 0 0}$ & $44.11 \pm 1.96$ & $47.35 \pm 1.69$ & $3.24 \pm 1.53$ & 6.84 & $0.24 \pm 0.01$ & 0.51 \\
\hline
\end{tabular}

All values are Means \pm SD

The spermatogenic and Meiotic indexes provide valuable information for the evaluation of the efficiency of spermatogenesis. There was no significant variation in the calculated indexes among treatments. However, the indexes of mice administered $500 \mathrm{mg} / \mathrm{kg}$ dose showed nonsignificant increases in all the indexes evaluated (Table 2)

Table 2:Volumetric Proportions of Seminiferous tubules and spermatogenic elements in Swiss albino mice treated with aqueous extract of Acanthus montanus

\begin{tabular}{|llll|}
\hline Parameters & Control & $\mathbf{5 0 0 m g} / \mathbf{k g}$ & $\mathbf{1 0 0 0} \mathbf{m g} / \mathbf{k g}$ \\
\hline Seminiferous Tubules & $82.45 \pm 3.16$ & $87.68 \pm 2.55$ & $83.34 \pm 1.65$ \\
\hline SpgA & $1.05 \pm 0.14$ & $1.08 \pm 0.31$ & $1.02 \pm 0.23$ \\
\hline $\mathbf{1}^{\mathbf{0}}$ Spc(Prelep/Lep) & $16.81 \pm 1.74$ & $19.36 \pm 1.86$ & $17.55 \pm 1.53$ \\
\hline Pachytene & $20.15 \pm 1.80$ & $20.82 \pm 1.68$ & $20.16 \pm 1.55$ \\
\hline Rtds & $61.95 \pm 1.85$ & $67.24 \pm 1.72$ & $63.18 \pm 1.69$ \\
\hline Spermatogenic Index & $16.67 \pm 0.1 .02$ & $17.93 \pm 1.25$ & $17.20 \pm 1.21$ \\
\hline Meiotic Index & $3.07 \pm 0.25$ & $3.22 \pm 0.41$ & $3.13 \pm 0.22$ \\
\hline Spermatogonic Yield & $59.00 \pm 4.56$ & $62.25 \pm 5.23$ & $61.94 \pm 5.18$ \\
\hline
\end{tabular}

$1^{\circ} \mathrm{spc}(\operatorname{Prelep} /$ Lep $)=$ Primary spermatocytes at Preleptotene/Leptotene $\mathrm{Spg} A=$ spermatogonia A,Rtds=round spermatids.Mitotic index was estimated as the ratio primary spermatocytes at Preleptotene/Leptotene to spermatogonia A.Meiotic index was the estimate of the ratio of round spermatids to that of primary 
spermatocytes at Pachytene.Spermatogenic yield was the estimate of round spermatids produced per spermatogonium A .All values are Means \pm SD * Significant at $\mathbf{P}<0.05$

The results of the preliminary evaluation of aqueous leaf extract of Acanthus montanus on spermatogenesis in mice are shown in Figures 1,2 and 3. The testicular micrographs during spermatogenesis in mice administered distilled water for 21 days showed seminiferous tubules at various stages of spermatogenesis and spermiogenesis with the seminiferoius epithelium presenting normal germ cell components of mitotic spermatogonia and meiotic primary spermatocytes at pachytene (P) as well as elongating spermatids (el)(Fig.1A-C) .Fig.1D,E\& show seminiferous tubules during spermiation.Note the lumen (L) filled with spermatozoa (spz) and the clusters of Leydig cells in the interstitial compartment (IC). Normal spermatogenic processes including spermatozoa elongation, spermiation (arrows) and active mitotic division (*) are presented in Fig.1E \&F. while Fig.1G shows seminiferous epithelium after spermiation.
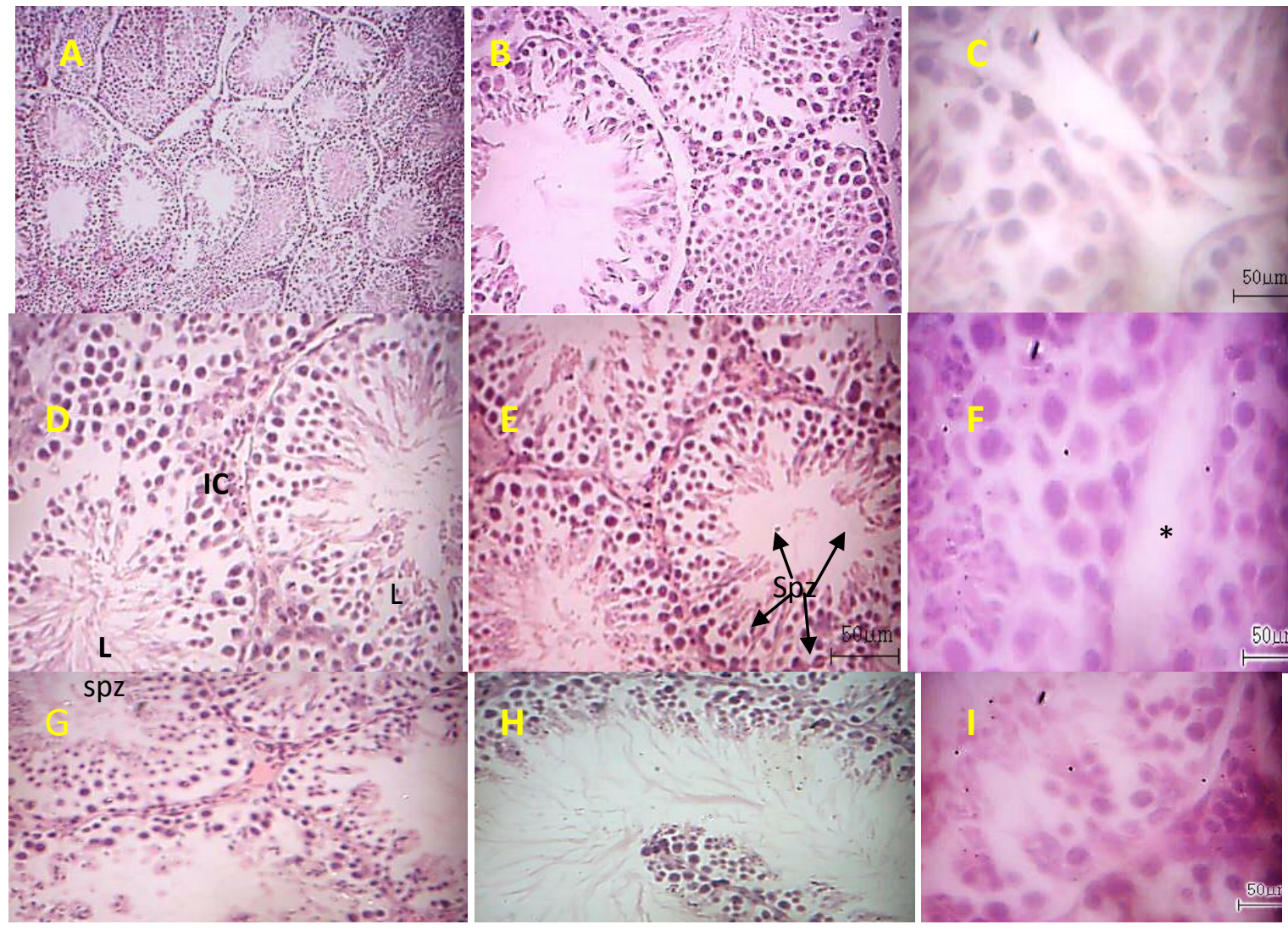

Fig.1: Images of spermatogenesis in control mice administered distilled water. Fig.1A shows seminiferous tubules at various stages of spermatogenesis and spermiogenesis.Fig.1B \&C are seminiferoius epithelium with normal germ cell components at late stage of spermatogenesis with elongating spermatids (el).Fig.1D,E\&F show seminiferous tubules during spermiation.Note the lumen $(\mathbf{L})$ filled with spermatozoa (spz) in D,clusters of Leydig cells are found in the interstitial compartment. Fig.1 E shows mature permatozoa ready for spermiation (arrows).Fig.1F shows seminiferous epithelium undergoing active mitotic division (*)Fig.1G,H\&I show seminiferous epithelium after spermiation.

Administration of aqueous extract of Acanthus montanus leaves at $500 \mathrm{mg} / \mathrm{kg}^{-1}$ bw for 21 days gave a boost to the process of spermatogenesis in mice as visible in the micrographs in Fig.2A-G.The lumen of most of the seminiferous tubules observed at low power are filled with spermatozoa following spermiogenesis (Fig.2A\&B). There was an appreciable increase in the number of germ cells undergoing spermatogenesis as the epithelium appeared overcrowded with germ cells.There were gaps in the seminiferous epithelium which presented with normal germ cell components.Active spermatogenic activity was exhibited as tubules containing elongating spermatids (Fig.2C).Fig.D,E,F,\&G shows tubules at spermiation with the lumen filled with spermatozoa released from the Sertoli cells.At $500 \mathrm{mg} / \mathrm{kg}^{-1} \mathrm{bw}$ leaf extract of Acanthus montanus appeared to increase spermatogenic activity in mice and reduce germ cell loss. 

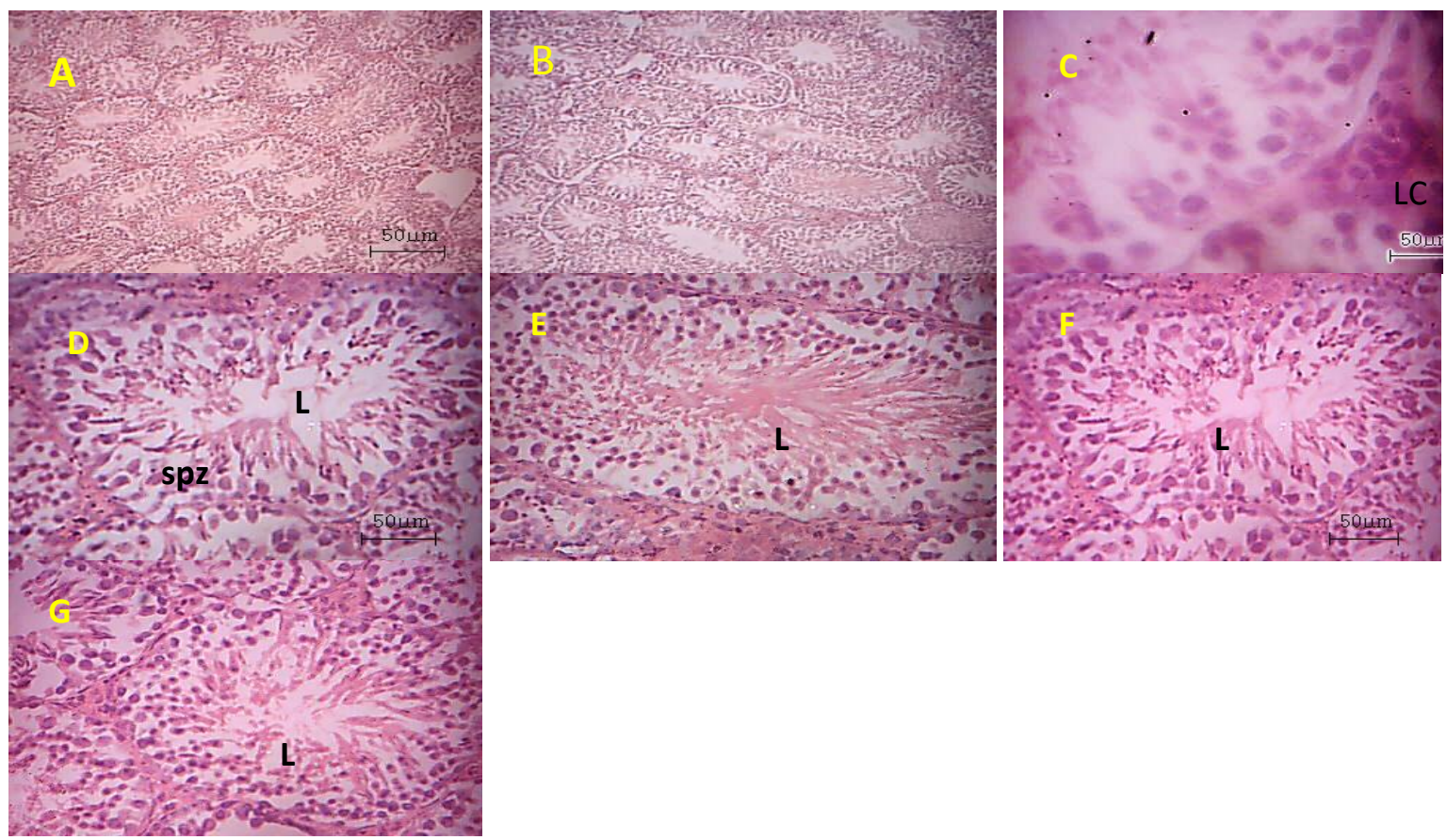

Fig.2A-G: Micrographs of the seminiferous epithelium of mice administered aqueous extract of Acanthus montanus leaves at $500 \mathrm{mg} / \mathrm{kg}^{-1}$ body weight. Fig.2A\&B show seminiferous tubules at various stages of spermatogenesis and spermiogenesis.Fig.2C is an epithelium at late stage with elongating spermatids.Fig.D,E,F,\&G tubules at spermiation with the lumen filled with spermatozoa released from the Sertoli cells.There is increase in spermatozoa,primary spermatocytes, leydig cells and spermatids

Fig.3A-G show micrographs of the seminiferous epithelium of mice administered aqueous leaf extract of Acanthus montanus at $1000 \mathrm{mg} / \mathrm{kg}^{-1}$. Fig. $3 \mathrm{~A}$ shows seminiferous tubules at various stages of spermatogenesis.Fig.3B,C,D\&E show seminiferous epithelium undergoing spermatogenesis and spermiation with appreciable decrease in the number of spermatogenic cells present in the epithelium.Fig.3C\&D show detachment of the germ cells from the basement membrane, as well as, gaps $\left(^{*}\right)$ in the seminferous epithelium indicating germ cell loss.Fig. $3 \mathrm{~F} \& \mathrm{G}$ highlights this phenomenon with empty spaces arising from loss of mostly primary spermatocytes.
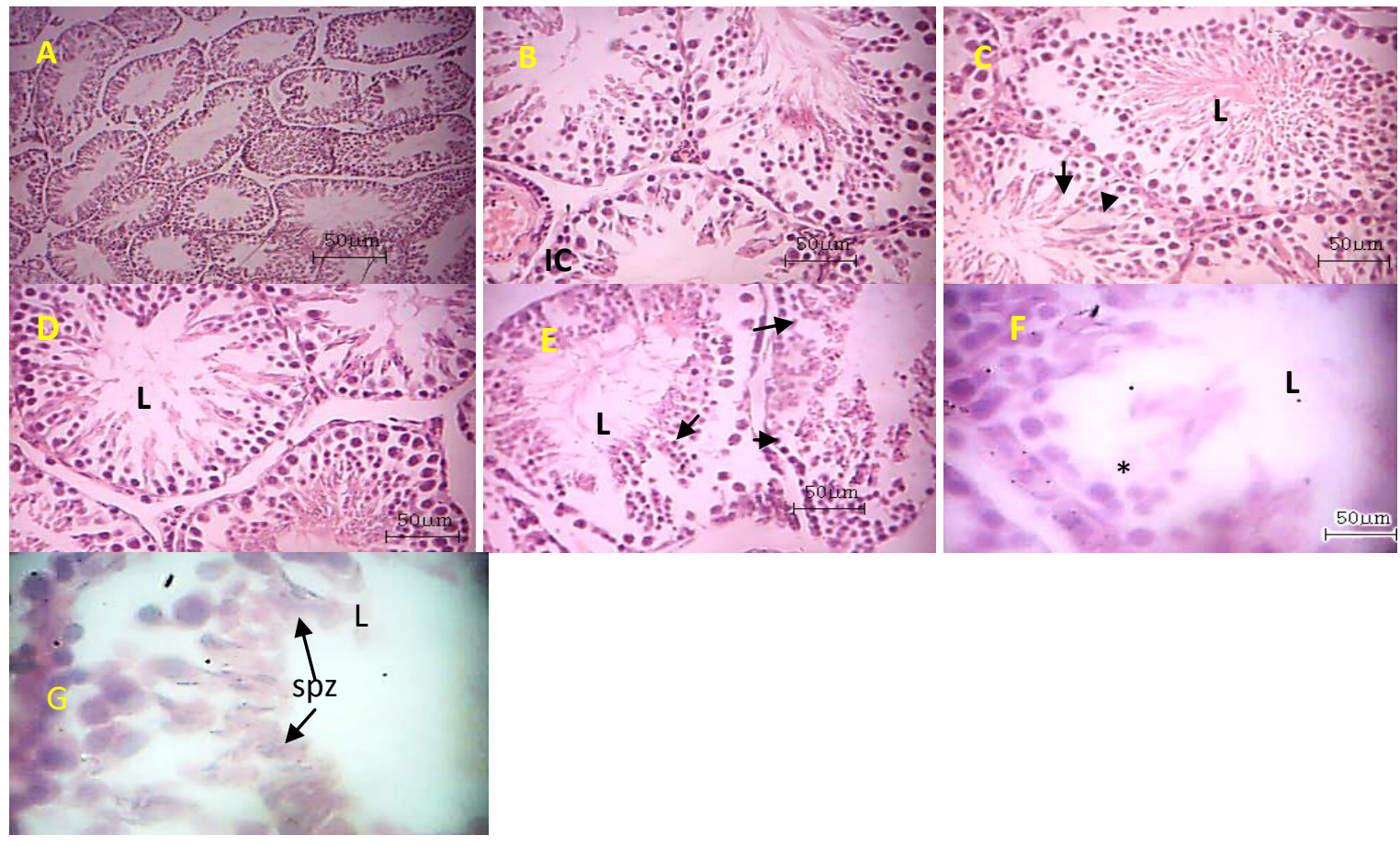
Fig.3A-G Micrographs of the seminiferous epithelium of mice administered aqueous leaf extract of Acanthus montanus at $1000 \mathrm{mg} / \mathrm{kg}^{-1}$. Fig.3A shows seminiferous tubules at various stages of spermatogenesis.Fig.3B,C,D\&E show seminiferous epithelium undergoing spermiation with appreciable decrease in the number of spermatogenic cells present in the epithelium.Fig.3C\&D show detachment of the germ cells from the basement membrane, as well as, gaps $\left(^{*}\right)$ in the seminferous epithelium indicating germ cell loss.Fig.3F \&G highlights this phenomenon with empty spaces arising from loss of mostly primary spermatocytes.

\section{Discussion}

No significant increase was observed in the body weight of mice treated with aqueous extract of the leaves of Acanthus montanus even at high concentrations $(1000 \mathrm{mg} / \mathrm{kg}$ bw.)This lack of alteration in the body weight of treated mice indicates non systemic toxicity of the extract even at $1000 \mathrm{mg} / \mathrm{kg}$ body weight/day.

However a non significant increase in testicular mass and parenchyma was noted in mice treated with $500 \mathrm{mg} / \mathrm{kg}$. This increase reflected in an increase in the volumetric proportion of seminiferous tubules which in turn is indicative of increased spermatogenic activity and proliferation of germ cells. Similar results have been reported with extracts of Lepidium meyenii [13] and Cynomorium coccineum [14]. A positive linear correlation between testis weight and daily sperm production and reserves potentials has been documented in the domestic fowl [9], spermatogenic indexes [8] hence an increase in testicular parenchyma results in an increase spermatogenic potential.

Aqueous leaves extract of Acanthus montanus inhibited sperm production at the concentration of $1000 \mathrm{mg} / \mathrm{kg}^{-1}$ bw evidenced by the reduction in the number of spermatogenic cells. Similar results were found by the administration of Colebrookia oppositifolia in rats[15] and Mentha arvensis in mice [16] Lepidagathis alopecuroides in Clarias gariepinus [17],in Sprague Dawley rats [10]

There was no significant difference in the gonadosomatic index (GSI) of control and treated mice an indication that the weight of testicular parenchyma was not significantly reduced.There was a trend of increase in percent body weight, as well as, increase in the testicular parenchyma weight in mice treated with $500 \mathrm{mg} / \mathrm{kg}$ bw./day.

Quantitative evaluation of the spermatogenic elements in the testiscular cross-section is important for the assessment of spermatogenesis and its efficiency, as well as, predicting the sperm production and the kinetics of spermatogenesis [18].Similar trend of increase in the spermatogenic indexes, including mitotic index, meiotic index and spermatogenic yield in the animals treated with $500 \mathrm{mg} / \mathrm{kg}$ A. montanus extract is a strong indication of that A.montanus leaves extract may possess the potential to be beneficial in the improvement of sperm production in males, however, further investigation is required

\section{CONCLUSION}

Therefore, the presented data suggests that treatment with a high dose of A.montanus extract $(500 \mathrm{mg} / \mathrm{kg} / \mathrm{bw})$ promoted an increase in testicular weight, and led to a higher efficiency of the spermatogenic process. In addition, there were no visible alterations in the parenchyma that could compromise the spermatogenic process, there were also,no visible signs of reproductive or systemic toxicity. However, further investigation in recommended.

\section{References}

[1] Noumi.E..Fozi,F.L2003.Ethnomedical Botany of epilepsy treatment in Fongo-Tongo village,Western Province,Cameroon.Pharm.Biol.41 (5):330-339

[2] Djami, A.T., Asongalem, E.A., Nana, P., Choumessi, A., Kamtchouing, P., Asonganyi, T. (2011). Subacute toxicty study of aqueous extract from Acanthus montanus. Electronic Journal of Biology. 17(1): 11-15

[3] Okoli,C.O., Akah, P.A., Onuoha, N.J., Okoye, T.C., Nwoye, A.C., Nwosu, C.S.(2008). Acanthus montanus: an experimental evaluation of the antimicrobial, anti-inflamatory and immunological properties of a traditional remedy for furuncles. BMC Compl. And Alter. Med.,1(8):27

[4] Olufunmilayo, O.A., Steve, O.O., Orowo, O. (2004). The analgesic effect of the methanolic extract of Acanthus montanus. Journal of Ethnopharmacology 90(1):45-48.

[5] Asongalem, E.A., Nana, P., Foyet, H.S., Dimo, T., Kamtchouing, P.(2008). Antifertility and Fetotoxic activities of Acanthus montanus aqueous extract in Wistar rats. Journal of Ethnopharmacology. 116(2) 228-33.

[6] Nana, P., Asongalem, E.A., Foyet, H.S., Folefoc, G.N., Dimo, T., Kamtchouing, P.(2008). Maternal and developmental toxicicty evaluation of Acanthus montanus leaves extract administered orally to wistar pregnant rats during organogenesis. $J$. Ethnopharmacol., 116:228-233

[7] Foyet, H.S., Asongalem, E.A., Nana, P., Folefoc, G.N., Kamtchouing, P.(2006). Tocolytic effect of Acanthus montanus in rat uterus. Pharmacologyonline., 3:9-17

[8] Orlu, E.E., \& Egbunike, G.N. (2009).Daily Sperm production of the Domestic fowl (Gallus domesticus) determined by quantitative Testicular histology and homogenate methods. .Pakistan Journal of Biological Sciences, 12(20), 1359-1364

[9] Orlu, E.E.,\& Egbunike,G.N. (2010). Breed and seasonal variation in the Testicular Histometric parameters and Germ cell populations of the barred Plymouth Rock and the Nigerian indigenous breeds of the domestic fowl (Gallus domesticus). Journal of Applied Sciences, 10 (13),1271-1278 
[10] Orlu, E. E. and Ogbalu, O.K. 2012. Partial Inhibitory Effect of Ethanol Extract of Lepidagathis alopecuroides (Vahl) on Spermatogenesis in Sprague-Dawley Rats. International Journal of Animal and Veterinary Advances, 4(3): 214-220

[11] Abercrombie M. Estimation of nuclear population from microtome sections. Anat Res 1946; 94: 238-43.

[12] Berndtson,W.E.1977.Methods for quantifying mammalian spermatogenesis:A review.J.Anim.Sci.44,818-833

[13] Gonzales, G.F, Cordova, A. Gonzales, C., Chung, A. Vega, K. Villena, A. 2001. Lepidium meyeii (Maca) improved semen parameters in adult men. Asian J Androl 3: 301-303.

[14] Abdel-Magied, E.M, Abdel-Rahman, H.A, Harraz, F.M 2001. The effect of aqueous extracts of Cynomorium coccineum and Withania somnifera on testicular development in immature Wistar rats. J Ethnopharmacology 75:1-4.

[15] Sharma N, Jacob D.2001. Antifertility investigation and toxicological screening of the petroleum ether extract of the leaves of Mentha arvensis L. in male albino mice. J Ethnopharmacol 75: 5-12

[16] Gupta RS, Yadav R, Dixit VP, Dobhal MP.2001. Antifertility studies of Colebrookia oppositifolia leaf extract in male rats with special reference to testicular cell population dynamics. Fitoterapia 72 (3), 236-45.

[17] Orlu, E.E., \& Gabbriel,U.U. 2011. Effect of sublethal concentrations of Lepidagathis alopecuroides aqueous extract on the efficiency of spermatogenesis in gravid broodstock Fresh water African catfish Clarias gariepinus. Research Journal of Environmental Toxicology, 5 (1), 27-38

[18] Nkanga, E.E.1997. Kinetics of spermatogenesis and germ cell Degeneration of the domestic fowl (Gallus domesticus). Niger Delta Biologia, 2 (1a), 19-27. 